\title{
PENGARUH SIFAT FISIS KAYU JABON (Antochepalus cadamba)
}

\author{
Ningsie Indahsuary Uar*, M. S. Tuharea*, Nurfitri Hentihu* \\ *Staf Pengajar FPHUT UNIQRA-Buru, Email : indahsuaryneng78@gmail.com
}

\begin{abstract}
ABSTRAK
Penelitian bertujuan untuk mengetahui pengaruh sifat fisis kayu Jabon (Antochepalus cadamba) dan manfaat untuk memberikan informasi kepada industri dan masyarakat tentang sifat fisis kayu Jabon (A. cadamba). Alat yang digunakan dalam pengujian ini adalah kaliper, oven, timbangan elektrik dan desikator, sedangkan bahan utama dalam penelitian ini adalah satu batang kayu Jabon (A. cadamba) yang berumur \pm 7 tahun dengan diameter $35 \mathrm{~cm}$ dan tinggi bebas cabang $\pm 8 \mathrm{~m}$. Hasil Penelitian Kadar air tertinggi pada posisi aksial /bagian batang (Pangkal, tengah, dan ujung) terdapat pada bagian ujung sebesar $74,65 \%$ dan kerapatan tertinggi terdapat pada bagian tengah $0.107 \mathrm{~g} / \mathrm{Cm}^{3} . \mathrm{Kadar}$ Air tertinggi pada psoisi radial/ bagian bidang pohon (kulit, tengah, dan empulur) terdapat pada bagian empulur $76.14 \%$ dan kerapatan teringgi terdapat pada bagian Pangkal. Tingkat Penyusutan tertinggi yang dilihat dari bagian batang pohon tertinggi pada bagian pangkal 70.4 bidang tangensial. Tingkat Penyusutan tertinggi yang dilihat dari bagian bidang pohon terbesar terdapat pada bagian kulit bidang tangensial. Hasil analisisis sidik ragam kadar air, kerapatan kayu dan penyusutan tidak signifikan.
\end{abstract}

Kata Kunci : Sifat fisis, Jabon, Antochepalus cadamba

\section{PENDAHULUAN}

\subsection{Latar Belakang}

Penggunaan kayu untuk kebutuhan dulu hingga sekarang sangat meningkat, seperti untuk konstruksi rumah, industri meubel atau dan lain-lain. Selain itu kayu memiliki ciri-ciri struktur fisika dan kimia yang unik. Kayu merupakan bahan baku industri yang sudah lama dikenal di masyarakat mulai dari yang ada di desa sampai di kota-kota besar. Dalam kehidupan sehari-hari sering ditemukan istilah seperti kayu basah, kayu kering, kayu keras, kayu lunak, kayu kuat dan sebagainya. Kayu berasal dari berbagai jenis pohon yang mempunyai sifat berbeda, bahkan kayu yang berasal dari satu jenis pohon pun memiliki sifat yang berbeda jika dibandingkan pada bagian pangkal, tengah dan ujung (Kailola, 2006)

Sifat dasar dari jenis-jenis kayu Indonesia yang dapat dikatakan lengkap hanya berat jenis, kelas kuat dan kelas awet. Tetapi data kelas kuat yang ada itu sebenarnya masih kurang akurat karena kebanyakan hanya ditaksir berdasarkan Berat jenis. Agar dapat dimanfaatkan secara efisien maka diperlukan data cermat

Mengenai sifat anatomi, kimia, fisik dan mekanik dari setiap jenis kayu. Kekuatan

Kayu memiliki peranan penting dalam penggunaan kayu untuk bangunan, perkakas dan keperluan lainnya sehingga klasifikasi kekuatan kayu dapat dipakai

Sebagai pedoman dalam penentuan penggunaan suatu jenis kayu (Lempang, 2014).

Sementara itu menurut (Mansur dan Tuheteru 2010) Salah satu jenis tanaman hutan rakyat yang sedang marak dikembangkan dalam beberapa tahun terakhir ini adalah tanaman Jabon (Arthocephalus cadamba). Ada beberapa alasan yang menyebabkan tanaman ini lebih dipilih untuk dikembangkan, diantaranya yaitu: tanaman jabon merupakan tanaman yang cepat tumbuh, memiliki tingkat kesilindrisan batang yang cukup tinggi, mata 
kayunya relatif sedikit, dan memiliki sifat fisis dan mekanis yang cukup baik.

\subsection{Tujuan dan Manfaat Penelitian}

Penelitian ini bertujuan untuk Mengetahui sifat fisis kayu Jabon pada bagian pangkal, tengah, dan ujung. Manfaat dari penelitian adalah untuk memberikan informasi kepada industri dan masyarakat tentang sifat fisis kayu Jabon (Antochepalus cadamba)

\section{METODOLOGI PENELITIAN}

\subsection{Waktu dan Tempat Penelitian}

Penelitian ini dilaksanakan pada bulan Agustus 2015 di Laboratorium Fak. Tarbiyah dan Ilmu Pendidikan IAIN Ambon.

\subsection{Alat dan Bahan}

Alat yang digunakan dalam pengujian sifat fisis adalah Gergaji potong,kaliper, oven, timbangan elektrik dan desikator, sedangkan bahan utama dalam penelitian ini adalah satu batang kayu Jabon (A. cadamba) yang berumur \pm 7 tahun, tinggi pohon $9 \mathrm{~m}$ dengan diameter 35 $\mathrm{cm}$ dan tinggi bebas cabang $\pm 8 \mathrm{~m}$.

\subsection{Prosedur Kerja}

Metode yang digunakan dalam penelitian ini terdiri dari beberapa tahapan meliputi persiapan bahan baku, pengujian sifat fisis, dan pengolahan data.

\subsection{Persiapan Bahan Baku}

Pohon jabon yang sudah dipilih, ditebang pada ketinggian $15 \mathrm{~cm}$ dari tanah, kemudian dipotong menjadi tiga bagian yaitu pangkal, tengah dan Ujung dengan panjang $100 \mathrm{~cm}$ dan jarak $140 \mathrm{~cm}$ kemudian dalam satu bagian diambil contoh uji pada bidang radial, tangensial, untuk sampel tersebut kemudian di bungkus menggunakan almunium voil mencegah penurunan kadar air. untuk selanjutnya sampel di potong sesuai dengan ukuran yang ditentukan dan tujuan pengujian.
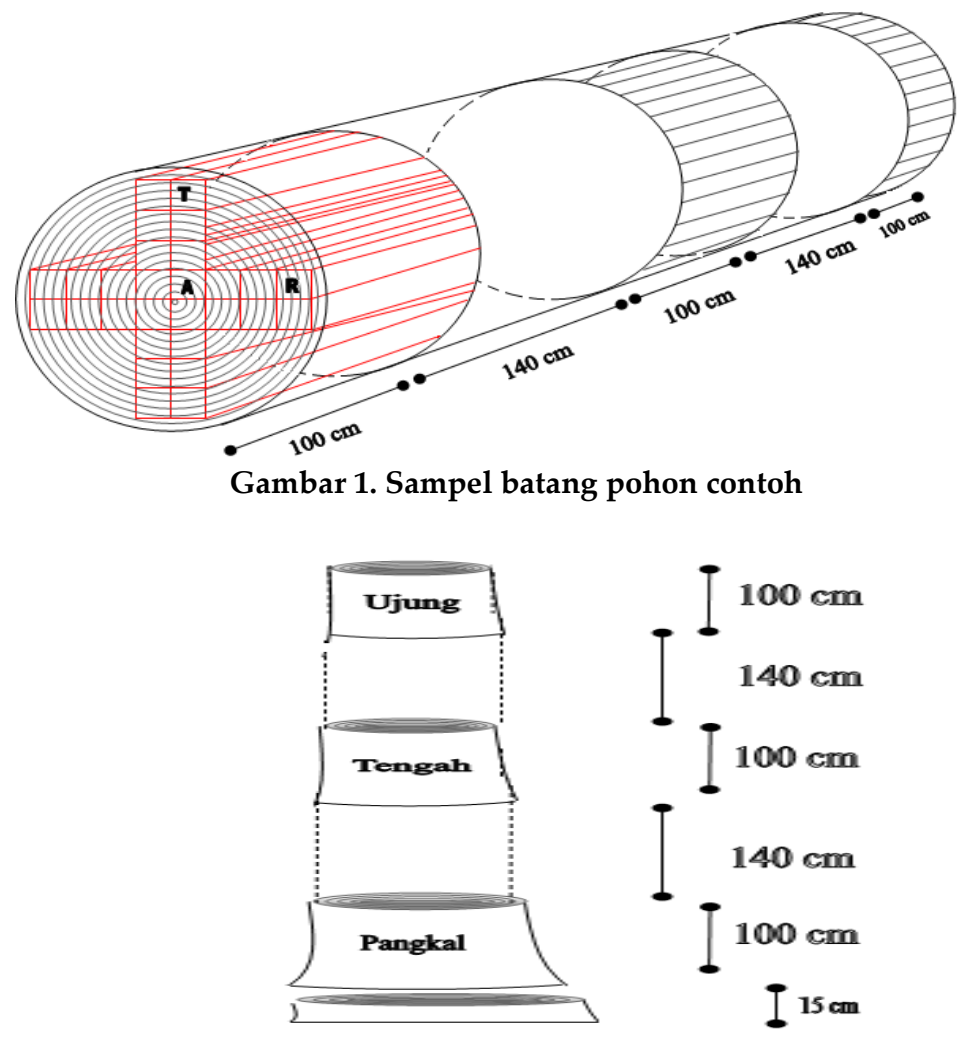

Gambar 2. Sampel pemotongan batang pohon

\subsection{Pengujian Sifat Fisis}

Sifat fisis yang di ujikan pada sampel kayu meliputi kadar air, kerapatan kayu serta penyusutan dimensi. a. Kadar Air dan Kerapatan

Dari satu pohon contoh dengan pada posisi arah tiga bagian batang pohon (pangkal, tengah, dan ujung), dan tiap-tiap bagian 
batang pohon di ambil bagian luar/kulit, , dalam dan, empulur diambil contoh kayu dengan ukuran $2 \times 2 \times 2 \mathrm{~cm}$ sebanyak 3 dari masing-masing bagian. Masing-masing kayu ditimbang dan diukur volume. Selanjutnya sampel dioven dengan suhu $130 \pm 2^{\circ} \mathrm{C}$ selama 24 jam untuk memperoleh berat kering tanur atau sampai mencapai berat konstan. Nilai kadar air dan kerapatan kayu masingmasing ditentukan dengan persamaan berikut:

$$
\mathrm{KA}(\%)=\frac{(B B-B K T)}{B K T} x \mathbf{1 0 0} \% ; \rho\left(\mathrm{g} / \mathbf{c m}^{3}\right)=\frac{(B B)}{V o l}
$$

dimana KA adalah kadar Air (\%), @ adalah kepatan $\left(\mathrm{g} / \mathrm{cm}^{3}\right)$, BB adalah berat awal/basah (g), BKT adalah berat kering tanur (g)

b. Penyusutan

Sampel Pengukuran dimensi berukuran $1 \times 1 \times 5 \mathrm{Cm}$ ini kemudian di ukur menggunakan kaliper. Penyusutan masingmasing bidang untuk seluruh kondisi nilai penyusutan dihitung dengan persamaan :

$$
\% \text { Penyusutan }=\frac{(D i 1-D i 2)}{D i 1} \times 100 \%
$$

dimana Di1 adalah dimensi lebar awal, Di2 adalah dimensi lebar akhir, I, adalah arah tangensial dan radial

\subsection{Analisis data}

Analisis data sifat fisis dalam penilitian ini dilakukan dengan analisis deskriptif sederhana untuk menentukan nilai rata-rata. Untuk mengetahui pengaruh posisi kayu dan bidang pengamatan dilakukan rancangan percobaan acak lengkap dua faktorial dengan faktor A adalah variasi posisi kayu dan faktor $B$ adalah variasi bidang pengamatan. Ulangan yang dilakukan adalah tiga kali

\section{HASIL DAN PEMBAHASAN}

\subsection{Kadar Air dan Kerapatan Kayu}

Hasil penilitian Gambar 3, menunjukan kadar air bervariasi mulai dari yang tertinggi pada tiga bagian yakni ujung sebesar 74.65, selanjutnya tengah 62,64 dan terendah pada bagian pangkal sebesar 58.16. Pada umumnya kadar air pohon berdiri tertinggi pada bagian pangkal, selanjutnya bagian tengah dan paling terkecil pada bagian ujung. Kecenderungan kadar air pada arah aksial sesuai dengan pernyataan Koch diacu Siarudin dan Marsoem
(2007) bahwa pangkal pohon biasanya memiliki kadar air tertinggi dan akan menurun secara teratur ke arah ujung pohon. Diduga hal ini disebabkan oleh besarnya rongga sel pada bagian pangkal sehingga memiliki kerapatan terendah.

Variasi kadar air pada hasil penilitian yang tidak terlalu berbeda diasumsikan bahwa peralihan musim. Manuhuwa (2007), menyatakan bahwa musim sangat berpengaruh terhadap kadar air segar, pada musim penghujan kadar air akan lebih tinggi dibandingkan pada musim kemarau. Selain itu tempat tumbuh, lokasi geografis, iklim, maupun spesies itu sendiri merupakan faktor yang mempengaruhi kadar air, faktor tersebut dapat berpengaruh terhadap kapasitas sel yang mana berpengaruh terhadap kapasitas menampung molekul air dalam sel (Baker et al diacu Savitri., 2012). sedangkan kerapatan kayu tertinggi pada bagian tengah, kemudian bagian ujung dan makin menurun pada bagian pangkal. Kerapatan kayu berhubungan dengan kadar air, dimana kayu dengan kadar air yang besar umumnya mempunyai berat jenis lebih rendah (Kasmudjo, 2010). Kerapatan suatu jenis kayu tergantung dari jumlah zat kayu yang tersusun, rongga selnya, jumlah pori, kadar air yang terkandung didalamnya dan zat-zat ekstraktifnya.

Berat kayu juga dipengaruhi oleh banyaknya pori dalam kayu. Semakin banyak pori pada kayu, maka semakin ringan dan sebaliknya kayu yang kurang memiliki pori maka kayu tersebut akan semakin berat. Jika kerapatan untuk setiap bagian posisi batang (pangkal, tengah, ujung) dirata-ratakan maka nilai kerapatan tertinggi terdapat pada bagian tengah kemudian diikuti bagian ujung dan pangkal. Namun nilai kerapatan Jabon pada posisi batang tersebut tidak berbeda jauh. Sebagaimana dikemukakan oleh Tsoumis diacu Risnasari (2008) bahwa variasi kerapatan diantara pohon pada jenis yang sama dapat dipengaruhi oleh kondisi lingkungan (seperti tanah, iklim, dan tempat tumbuh) dan keturunan (heredity). Selain itu juga dapat disebabkan oleh keadaan abnormalitas dari pohon seperti kayu tarik dan kayu tekan (compression and tension wood). 


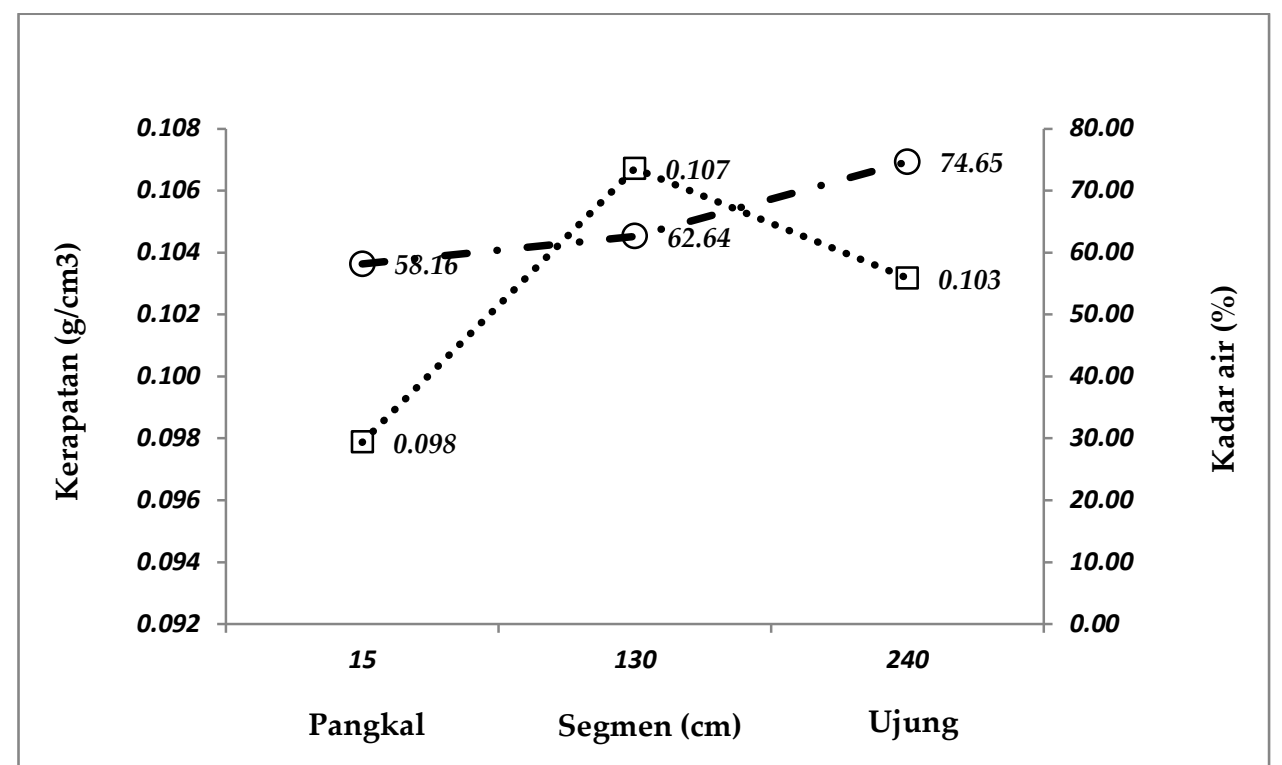

Gambar 3. Kadar air ( $\odot$ ) dan kerapatan kayu ( $\square)$ batang pohon contoh dari Pangkal ke ujung

Sementara itu hasil penelitian juga menunjukan kadar air tertinggi dari tiga bagian pada posisi radial mulai dari bagian kulit sampai empulur menunjukan kadar air tertinggi pada bagian empulur, kemudian bagian tengah dan makin menurun pada bagian kulit/ luar, sedangkan kerapatan kayu bervariasi mulai dari bagian kulit sampai ke bagian empulur (Gambar 4). Kadar air tertinggi pada bagian empulur 76.14, kemudian tengah 58.98 dan terkecil pada bagian luar 55.24 . Hal ini sesuai dengan pendapat Uar, 2014 kayu dibagian empulur mempunyai dinding sel yang tipis dan kurang padat sehingga rongga-rongga sel kayu tidak menyatu mengakibatkan kadar air pada daerah ini meningkat. Marsoem 1999 diacu Manuhuwa, 2007, menyatakan bahwa banyak jenis kayu di Indonesia yang kadar airnya tinggi di dekat empulur, diantaranya adalah akasia mangium, akasia auri, jati dan beberapa jenis lagi. Penilitian Uar, 2014 pada jenis A. Microcarpa juga menunjukan bahwa kadar air pada tiga bagian posisi radial tertinggi pada bagian empulur, kemudian tengah dan semakin menurun pada bagian luar. Semakin menurun kadar air maka akan berpengaruh juga terhadap kerapatan kayu. Perbedaan yang tidak terlalu jauh dari masingmasing bagian ditunjukan dengan hasil uji statistik pada selang kepercayaan 95 persen menunjukan tidak signifikan.

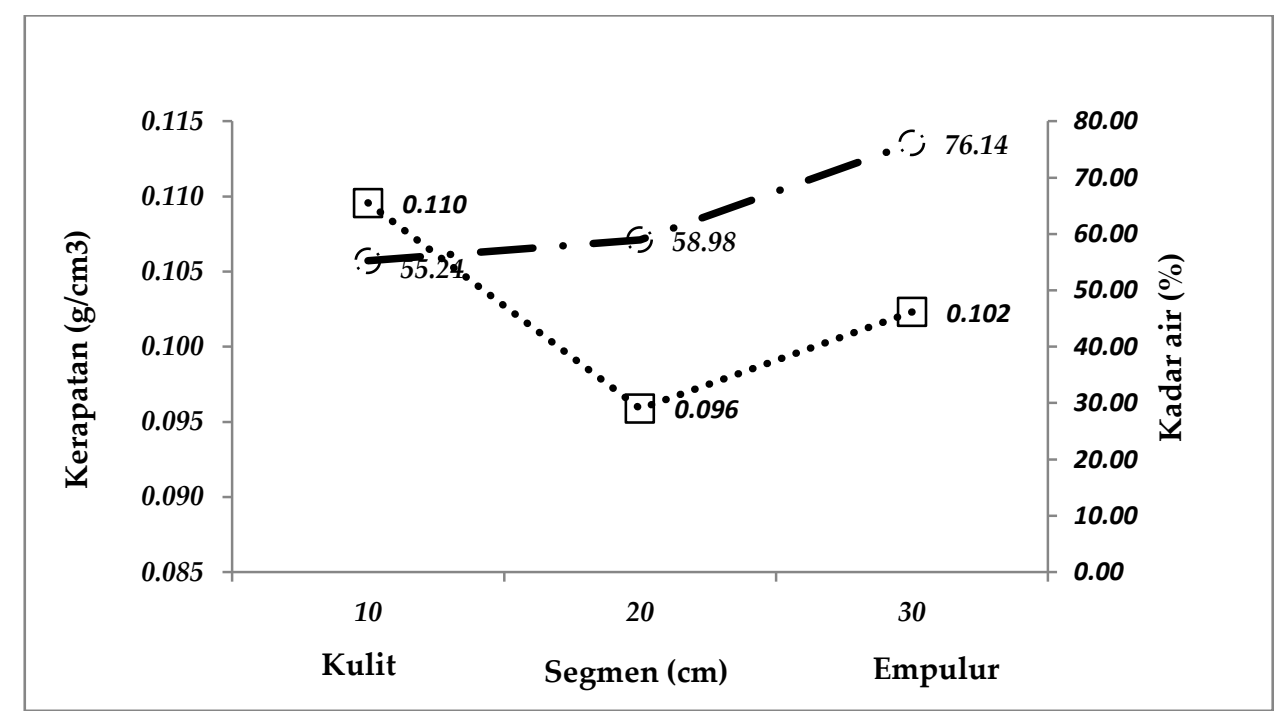

Gambar 4. Kadar air ( $\circ$ ) dan kerapatan kayu ( $\square)$ batang pohon contoh dari bidang kulit ke empulur 


\subsection{Penyusutan}

Berdasarkan hasil penilitian penyusutan kayu jabon menunjukan penyusutan arah tangensial lebih besar, dibandingkan bagian tengah dan ujung. Penilitian Savitri 2012, pada jenis Jabon juga menujukan hasil penyusutan terbesar arah tangensial pada bagian pangkal. Sementara itu hasil penilitian Lempang, 2014, pada jenis Jabon merah menunjukan penyusutan terbesar pada arah tangensial dengan rata-rata sebesar $1.37 \%$. Hal ini sejalan dengan pendapat Panshin dan de Zeeuw (1980) yang menyatakan bahwa penyusutan pada arah tangensial lebih besar daripada penyusutan pada arah radial, biasanya mencapai 2 kali atau lebih.

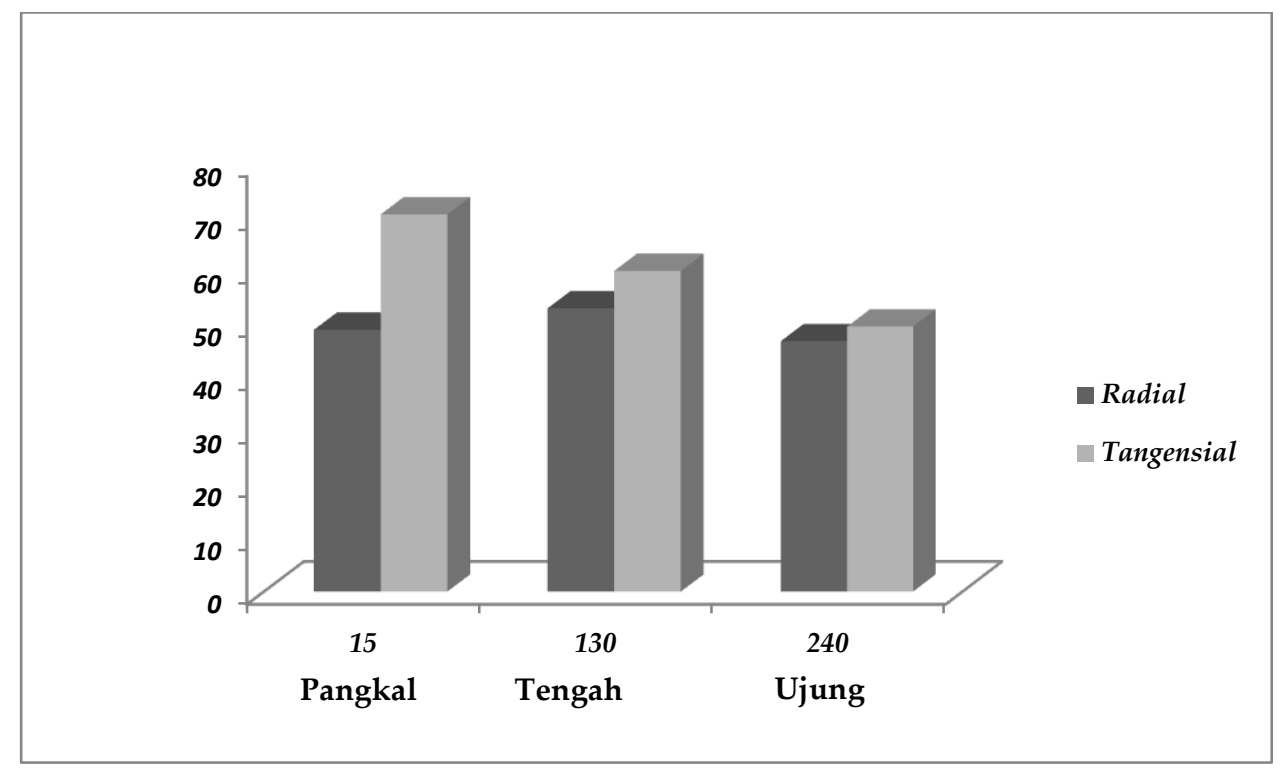

Gambar 5. Histogram nilai penyusutan pangkal, tengah dan ujung

Penyusutan merupakan akibat kehilangan air pada kayu di bawah titik jenuh serat yakni kehilangan air terikat. Kayu akan mengalami perubahan dimensi yang tidak sama pada ketiga arah strukturalnya. Pada arah longitudional penyusutan sangat kecil sehingga seringkali tidak diperhitungkan. Proses pengukuran tingkat penyusutan dilakukan setelah pengukuran kadar air karena semakin berkurangnya kadar air tingkat penyusutan pun bertambah dan dilakukan pengukuran sampai mendapat nilai yang konstan (Budianto,2000), menyatakan bahwa banyaknya tingkat penyusutan yang terjadi umumnya sebanding dengan jumlah air yang keluar dari dinding sel.

Hasil penilitian juga menunjukan penyusutan terbesar pada bagian pangkal, dan terkecil pada ujung. Hal ini sejalan dengan penelitian Kailola (2006), Savitri (2012), Ireeuw et al (2013). Namun hasil penilitian Risnasari (2009) menunjukan bahwa penyusutan bagian pangkal lebih kecil dibandingkan bagian lain karena pada bagian ini proporsi kayu teras lebih besar sehingga penyusutannya relatif lebih kecil. Hal ini diduga karena pada bagian pangkal contoh uji diambil dari bagian gubal sedangkan pada bagian tengah dan ujung contoh uji diambil dari bagian teras. Hasil penilitian Gambar 6 menunjukan bahwa penyusutan pada posisi bidang bervariasi mulai dari kulit sampai ke empulur namun penyusutan terbesar terdapat pada bidang tangensial. Hasil uji statistic pada selang kepercayaan 95\% juga menunjukan tidak ada perbedaan yang signifikan. Menurut Tobing 1976 diacu sutomo 2013, rendahnya nilai susut longitudinal disebabkan karena sebagian besar arah mikrofibril dalam lapisan dinding sel hampir sejajar terhadap sumbu sel, sedangkan susut tangensial yang besarnya dua kali dari susut radial, diakibatkan karena adanya tahanan jari-jari. 


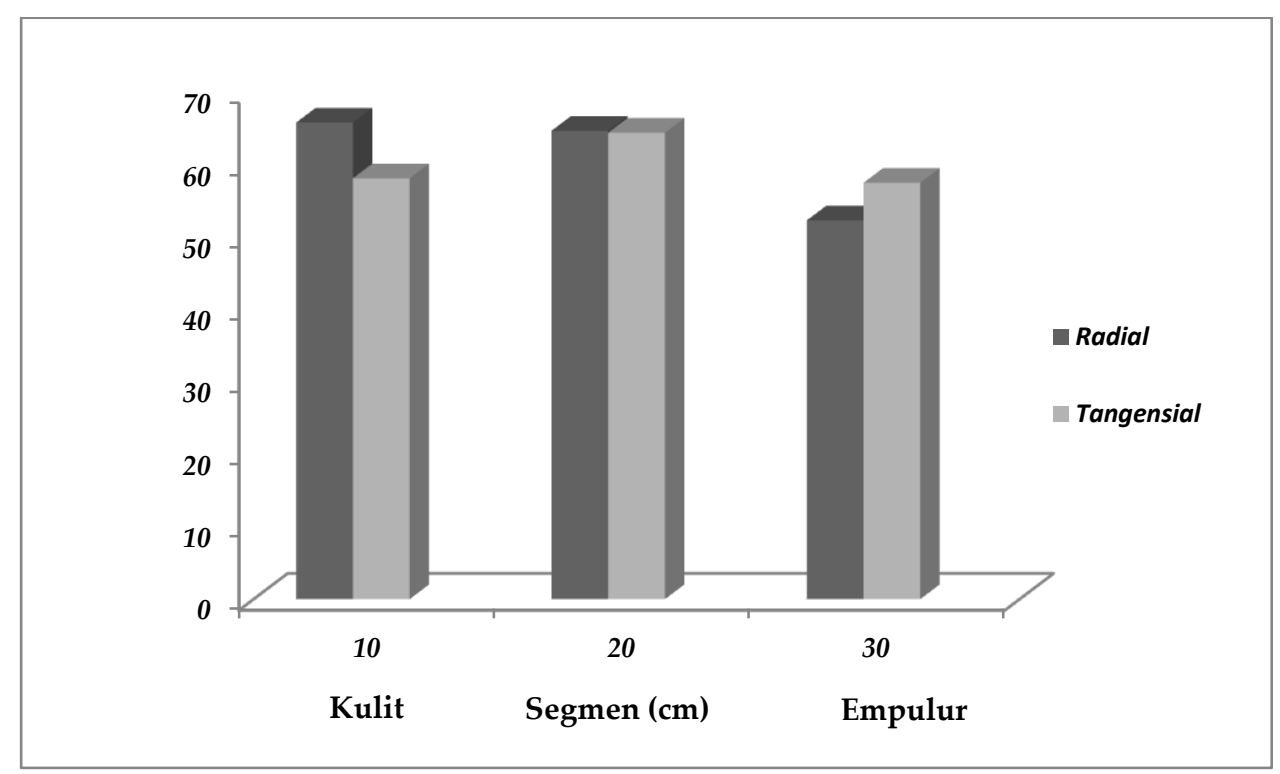

Gambar 6. Histogram nilai penyusutan kulit, tengah , dan empulur

Proses pengeringan merupakan salah cara mengurangi kadar air dalam kayu, dimensi kayu dapat berkurang atau menyusut dengan menurunnya kadar air kayu . Penyusutan dimensi kayu mulai diperhitungkan setelah kayu mencapai kadar air 30\% (kadar air. Titik jenuh serat) karena diatas nilai tersebut biasanya. penyusutan sangat kecil sehingga diabaikan. Stabilitas dimensi kayu ditunjukan oleh perbandingan penyusutan kayu pada arah tangensialnya kearah radialnya $(T / R)$. Lazimnya kayu yang nilai $T / R$ dibawah 2 dimensinya lebih stabil selama pengeringan. penyusutan merupakan keluarnya air dari dalam kayu sampai berada di bawah titik jenuh serat, penyusutan kayu terjadi pada umumnya pada arah longitudinal sebesar 0,1 - 0,2\%, arah radial sebesar 2,1 - 8,5 $\%$, selanjutnya arah tangensial $4,3-14 \%$, keadaan ini terdiri dari air bebas dan air terikat (Dumanauw 1982 diacu Kailola 2006)

Hasil penilitian Tabel 1. Menunjukan bahwa rata kadar air, kerapatan dan tingkat penyusutan kayu Jabon, kadar air tertinggi pada bagian ujung dan menurun ke bagian tengah dan semakin berkurang pada bagian pangkal, sama halnya dengan kerapatan kayu dan penyusutan dimensi, semakin berkurang kadar air maka tingkat penyusutan kayu pun semakin tingkat begitupun dengan kerapatan kayu. Semakin banyak kandungan zat kayu pada dinding sel yang berarti semakin tebal dinding sel tersebut maka semakin tinggi juga berat jenisnya (Haygreen et al. 2003).

Hasil penilitian Kailola, 2006, pada beberapa jenis kayu unggulan Tobelo juga menunjukan tingkat penyusutan pada arah tangensial lebih besar dibandingkan dengan penyusutan radial pada posisi batang bagian pangkal. Hal ini sesuai dengan pendapat Haygreen dan Bowyer (1993) diacu Kailola (2006) yang mengatakan bahwa besarnya penyusutan umumnya sebanding dengan banyaknya air yang dikeluarkan dari dinding sel. Ini berarti bahwa species atau bagian kayu yang mempunyai berat jenis tinggi haruslah menyusut lebih banyak per persen perubahan kandungan air dibandingkan dengan species atau bagian kayu yang mempunyai berat jenis lebih rendah.

Tabel 1. Hasil pengukuran kadar air, kerapatan dan penyusutan

\begin{tabular}{lcccc}
\hline Posisi Batang & KA & Kerapatan $\left(\mathrm{g} / \mathrm{Cm}^{3}\right)$ & \multicolumn{2}{c}{ Penyusutan } \\
\hline & & & Radial & Tangensial \\
Pangkal & 56.63 & 0.098 & 48.98 & 70.50 \\
Tengah & 64.39 & 0.107 & 52.96 & 59.96 \\
Ujung & 89.29 & 0.103 & 46.87 & 49.56 \\
\hline
\end{tabular}




\section{PENUTUP}

1. Kadar air tertinggi yang dilihat pada bagian batang pohon (Pangkal, tengah, dan ujung) terdapat pada bagian ujung $74,65 \%$. Sedangkan Kadar Air tertinggi dilihat pada bagian bidang pohon (Kulit, Tengah, Dan empulur) terdapat pada bagian empulur $76.14 \%$

2. Kerapatan tertinggi terdapat pada bagian tengah $0.107 \mathrm{~g} / \mathrm{Cm}^{3}$ sedangkan kerapatan teringgi terdapat pada bagian kulit yang dilihat pada bagian bidang pohon.

Tingkat Penyusutan tertinggi yang dilihat dari bagian batang pohon tertinggi pada bagian pangkal 70.4 bidang tangensial. Sedangkan tingkat penyusutan tertinggi dilihat dari bagian bidang pohon terbesar terdapat pada bagian kulit bidang tangensial.

\section{DAFTAR PUSTAKA}

Anonim, 2011 Jabon/Kelampayan.http://st296671.sitekno.com (25 Desember 2011)

Belly Ireeuw, Reynold P. Kainde, Josephus I. Kalangi, Johan A. Rombang. 2013. Beberapa Sifat Fisik Gubal Angsana (Pterocarpus indicus)

Departemen Kehutanan, 2009. Statistik Kehutanan Indonesia. Jakarta:

Haygreen, 2003. Forest Products and Wood Science, An Introduction.

Krisnawati, 2011. Anthocephalus cadamba Miq. Ekologi, Silvikultur, dan Produktivitas. http://www.cifor.org (25 Desember 2011)

Kasmudjo. 2010. Teknologi Hasil Hutan. Cakrawala Media. Yogyakarta.

Kailola, 2006. Sifat Fisik Beberapa Jenis Kayu Unggulan Asal Tobelo Menurut Ketinggian Batang dan Kedalaman Batang. Jurnal Agroforestri Volume 1 nomor 1

Lempang M. 2014. Sifat Dasar dan Potensi Kegunaan Kayu Jabon Merah. Jurnal Penelitian Kehutanan Wallacea Vol. 3 No.2. Hal 163 - 175

Mansur dan Tuhuteru, 2010. Kayu Jabon. Bogor: Penebar Swadaya.

Martawijaya A, K Iding, K Kosasi, dan AP Soewanda. 1989. Atlas Kayu Indonesia Jilid II. Bogor: Badan Penelitian Dan Pengembangan Kehutanan. Departemen Kehutanan.

Risnasari, I. 2008. Kajian Sifat Fisis Kayu Sengon Pada Berbagai Bagian Dan Posisi Batang. USU eRepository. Medan

Siarudin, M. dan S. N. Marsoem. 2007. Karakteristik Dan Variasi Sifat Fisik Kayu Mangium (Acacia mangium Willd.) Pada Beberapa Jarak Tanam Dan Kedudukan Aksial-Radial. Jurnal Pemuliaan Tanaman Hutan, 1(1):1-11

Sutomo, 2013. http://ade12forest.blogspot.co.id/2013/07/sifat-sifat-kayu-terutama-terhadapair_8885.html

Tsoumis, 1991. Tsoumis G. 1991. Science and Technology of Wood (Structure Properties, Utilization). New York: Van Nostrand Reinhold.

Uar. N I. 2014. Reliability of sonic tomography to detect agarwood in Aquilaria microcarpa Baill. Jurnal of the Indian academy of Wood Science 11 (1): 65-71. 